\title{
The Determinants of Working Capital Management in the Egyptian SMEs
}

\author{
Ahmed Elbadry ${ }^{1}$ \\ ${ }^{1}$ Lecturer, Business Administration Department, Faculty of Commerce, Cairo University, Giza, Egypt. \\ Correspondence: Ahmed Elbadry, Lecturer, Business Administration Department, Faculty of Commerce, Cairo \\ University, Giza, Egypt.
}

Received: February 10, 2018

Accepted: March 4, 2018

Online Published: March 14, 2018

doi:10.5430/afr.v7n2p155

URL: https://doi.org/10.5430/afr.v7n2p155

\begin{abstract}
This paper explores the main determinants of working capital management in the Egyptian SMEs and explains its effect on working capital management. Also, it examines the relation between the main determinants of working capital management and each component of working capital management. Moreover, the paper examines the effect of working capital management and SMEs' profitability and capital structure. The study sample includes data for 138 SMEs working in Egypt and financed by the national bank of Egypt from 2010 to 2013. Data have been collected from SMEs financial statements for four years for each company. OLS regression models have been used to examine the effect of working capital determinants on working capital level measured by CCC. I used firm size and industry as control variables and robust my results using full regression models for every year of analysis. The main results reflect negative and significant effect of SMEs profitability, tangible fixed assets, and leverage on working capital. Also, the industry represents a significant factor in determining the level of working capital in the Egyptian SMEs. Moreover, the effect of working capital management and SMEs profitability and capital structure decisions has been examined. The results reflect that the Egyptian SMEs follow an aggressive policy as businesses hold low level working capital which leads to high return and high degree of risk (measured by LEVERAGE). The study limited to the Egyptian SMEs which are financed by the National Bank of Egypt.
\end{abstract}

Keywords: working capital management, small and medium size enterprises, capital structure, profitability.

\section{Introduction}

In finance, the main long term decisions include capital budgeting decision, which is related to investment decisions, and capital structure decision, which is related to financing decision. Also, we have short term decision which is related to working capital decisions (Malik and Bukhari, 2014). In literature, little attention has been given to the working capital management decisions and its main determinants; especially in the SMEs in Egypt.

In general, all businesses must balance between its liquidity and profitability. Accordingly, it is very risky for all businesses to give attention to profitability using long term investments and short term investments without considering its liquidity level which is related mainly to working capital management. Inadequate practices of working capital management leads to bankruptcy (Samiloglu \& Dermigunes, 2008). Also, if the bankruptcy is probable in large companies it will be with a higher probability in medium and small enterprises as a cause of inefficient management of working capital. Smith (1980) discussed two types of working capital policies which are aggressive and conservative policies. The aggressive policy states that businesses hold low level working capital which leads to high return and high degree of risk. On the other side, conservative working capital policy means that businesses hold high level of working capital which leads to low return and low degree of risk.

A lot of studies have focused on working capital and companies performance ((Jose et al., 1996; Shin and Soenen, 1998; Deloof, 2003; Padachi, 2006; Garcia-Teruel and Martinez-Solano, 2007; Raheman and Nasr, 2007). Most of these studies find a significant and negative relation between working capital, measured by cash conversion cycle and firm's profitability. Few studies have focused on the main determinants of working capital management in large companies (Goel and Anil, 2015; Supatanakornkij, 2014; Rostami, 2014) and very few studies have focused on SMEs (S. Ban os-Caballero et al., 2010). Little attention has been given to the main determinants of working capital in the Egyptian SMEs.

In this paper, I examine the main determinants of working capital management in the Egyptian SMEs. I collected 
data of 138 SMEs working in Egypt during the period from 2010 to 2013. OLS regression models have been used. My results indicate negative and significant effect of SMEs profitability, tangible fixed assets, and leverage. Also, the industry represents a significant factor in determining the level of working capital in the Egyptian SMEs. Moreover, the effect of working capital management and SMEs profitability and capital structure decisions has been examined. The results reflect that the Egyptian SMEs follow an aggressive policy as businesses hold low level working capital which leads to high return and high degree of risk.

The next section of this paper will discuss the specialness of SMEs in Egypt. Section three will discuss the main determinants of working capital management. Section four discusses methodology and hypotheses. My results presented in section five. Section six concludes.

\section{SMEs Specialness}

There are many definitions of small and medium size enterprises (SMEs). In Egypt, and according to the Law No. 141 (2004) on Development of MSEs, small enterprise is any business or sole proprietorship participate in economic activity (services, industrial, commercial or agricultural) which has paid-up capital equals 50.000 L.E or more, and do not exceed 1 million Egyptian pounds. Also, the number of employees shall not be more than 50 employees (Note 1). Worldwide, there are different definitions of SMEs summarized in table (1) as follows:

Table 1. Definitions of small and medium size enterprises worldwide

\begin{tabular}{llll}
\hline Financial Institution & $\begin{array}{l}\text { Maximum value of } \\
\text { assets (\$) }\end{array}$ & $\begin{array}{l}\text { Maximum Value of } \\
\text { revenue or Sales (\$) }\end{array}$ & $\begin{array}{l}\text { Maximum size of } \\
\text { Employees (\#) }\end{array}$ \\
\hline World Bank & $15,000,000$ & $15,000,000$ & 300 \\
IMF & None & $3,000,000$ & 100 \\
African Development & None & None & 50 \\
Bank & None & None & 200 \\
UNDP & \multicolumn{2}{c}{ Source: Gibson (2008), p.5. }
\end{tabular}

In Egypt, 99\% of private enterprises are micro, small and medium size enterprises. The majority of them are working in the services sector and none of them in the mining sector. Most of SMEs in Egypt, about 90\%, are working in manufacturing sector (51\%) and in wholesale trade sector (40.5\%) (Creative Associates International, 2014). Moukhtar and Abdelwahab (2015) stated that SMEs are playing a major role in the economic development. It represents $89 \%$ of the size of all industries in Egypt. Also, it participates in 47\% of the total employment in Egypt.

Most of SMEs assets are current assets and most of its financial sources of finance are short term because they face problems in raising long term finance (S. Ban os-Caballero et al., 2010). Accordingly, working capital management is an important issue for SMEs growth and existence. Moukhtar and Abdelwahab (2015) supported the same idea that the main challenge of SMEs in Egypt is the limited sources of finance. SMEs face obstacles in official financial services, which in turn act a working or fixed capital in a permanent way. They face high loan costs of their projects beside the unavailability of the used loan criteria and restrictions with the requested documents and guarantees. Also, they face other challenges like the complicated regulations which issued by many authorities in Egypt, lake of managerial experience, marketing problems, insufficient resources, training and technological support, lake of information about SMEs which disabled the government and private sector to help them in their problems.

Concerning the role of the Egyptian banking system in supporting SMEs (Note 2), In January (2016) the Central Bank of Egypt (CBE) announced that by 2020 credit to SMEs, of any commercial bank's loan book, must account for $20 \%$ at least. Also, SMEs with revenue between $\$ 130,000$ and $\$ 255,000$ can access loans at rates of less than 5\%, which is significantly lower than the CBE's main credit rate of $11.25 \%$.

In Egypt, bank loans provided to SMEs equal about 5\% compared to $8 \%$ in the MENA region and $18 \%$ in the middle income countries. Accordingly, there is new initiative by the Egyptian authorities to expand banks involvement in the SMEs businesses. As a way to convince the commercial banks in Egypt to lend SMEs, CBE reduced the required reserve ratio from $14 \%$ to $12 \%$ for every lender to SMEs. Moreover, CBE write off an amount equivalent to every facility credited to SMEs from the required reserve ratio.

\section{The Main Determinants of SMEs Working Capital}

Dečman and Sever (2012) defined working capital management as "management of quickly cashable assets and current liabilities i.e. short-term financing of current assets". Accordingly, most literature used cash conversion cycle 
(CCC) as a measurement of working capital (S. Baños-Caballero et al., 2010, 2012; Atseye et al., 2015). CCC deals with the management of accounts receivables, inventories and accounts payables. CCC equals the average collection period plus average age of inventory minus the average payment period (Gitman and Zutter, 2015, P.603).

According to S. Ban os-Caballero et al. (2010) the main determinants of working capital of SMEs are: Capacity to generate internal resources, Leverage, Growth opportunities, Size of the firm, age of the firm, Tangible fixed assets, Return and Industry. Atseye et al. (2015) stated endogenous determinants include size, age, profitability, market share, sales growth, operating risk and operating cash flow and stated exogenous determinants include GDP, interest rate and tax rate. Accordingly, the paper will concentrate on the most common endogenous determinants between literature studies.

\subsection{Return (RETURN)}

Theoretically, there is a strong relationship between liquidity and profitability. Most studies concluded that profitability are negatively related to the measurements of working capital measured by CCC (S. Ban os-Caballero et al., 2010; Chiou et al. (2006); Lazavridis and Tryfonidis (2006); Deloof (2003). Previous studies interpreted the negative relation between company's performance and working capital in many ways. First, the higher the performance of the company the greater the ability to access external finance and accordingly they can invest in more profitable investments. Second, the higher the performance of the company the higher the bargaining power with its suppliers and customers in the market.

Little evidence concluded positive relation between company's performance and its working capital (Nazir and Afza, 2009). They denied that companies with better performance are less concerned with better working capital management.

In our study, I follow the literature and use ROA as a proxy of SMEs' profitability and accordingly my first hypothesis is:

H1. There is a significant and negative relationship between SMEs performance measured by ROA the degree of working capital measured by CCC.

\subsection{Cash Flow from Internal Sources (CASH_FLOW)}

External sources of finance have a higher cost than internal sources. The higher degree of information asymmetry between creditors and investors make it difficult to raise capital from external sources with low cost especially in SMEs fund (S. Baños-Caballero et al., 2010).

Cash flow is the best measure of the ability of SMEs to generate internal sources of fund (S. Baños-Caballero et al., 2010). Cash flow can be measured as the ration of net income plus depreciation divided by total assets. The effect of cash flow on working capital is not identified.

S. Baños-Caballero et al., (2010) find negative and significant relation between CCC and cash flow as a proxy of the ability of firms to generate internal sources of finance in SMEs. Accordingly, my second hypothesis is:

H.2 There is a significant and negative relationship between SMEs cash flow and working capital measured by CCC.

\subsection{Tangible Fixed Assets (TANG_FA)}

According to literature, tangible fixed assets are important determinants of working capital. Different studies from different countries and different levels of analysis find a negative and significant relation between tangible fixed assets and working capital (S. Baños-Caballero et al., 2010; Kieschnick et al. 2006; Fazzari and Petersen, 1993). The degree of information asymmetry which is related to the intangible assets is higher than tangible assets. Accordingly, SMEs with more tangible assets have lower cost of funding and can raise capital easily. As a result, they can raise capital to invest in current assets with low cost and this will encourage it to increase its CCC (S. Baños-Caballero et al., 2010).

In this paper I will measure the ratio of tangible fixed assets as tangible assets divided by total assets and my third hypothesis is:

H3. There is a negative and significant relation between the level of tangible assets and SMEs working capital measured by CCC.

\subsection{Sales Growth (SALES_G)}

According to S. Baños-Caballero et al. (2010) sales growth opportunities affects SMEs working capital management. Higher growth rates are related with higher levels of inventories because companies hold more inventories to face the 
expected growth of sales. Accordingly, CCC will be positively related to growth of sales (Kieschnich et al., 2006).

But, sometimes higher growth opportunities may cause low levels of working capital. SMEs may use more credit purchases as a source of fund to face the expected growth opportunities. Also, SMEs may extend their credit sales to customers to increase sales in low demand periods.

Growth of sales will be calculated as the percentage of change in sales in this paper. Also, I cannot identify the direction of the relation between growth opportunities of sales and CCC. Accordingly, I will follow the results of S. Baños-Caballero et al. (2010) as they find that firms with high growth opportunities follow aggressive working capital policy and my fourth hypothesis is:

H4. There is a negative relationship between sales growth and working capital measured by CCC.

\subsection{Leverage (LEVERAGE)}

Literature proved that there is a negative relationship between leverage and working capital (Chiou et al., 2006; Rahman and Nasr, 2007; S. Baños-Caballero et al., 2010, Abbadi and Abbadi, 2013). The higher degree of leverage reflects a higher degree of risk premium. Also, companies with high levels of leverage tend to invest less in working capital. In this paper I use the ratio of total debt to total assets as a measure of leverage and use total long debt and short term debt in the robustness of my results. Accordingly, my fifth hypothesis is:

H5. There is a negative relationship between leverage and working capital measured by CCC.

\subsection{Firm Size (SIZE)}

There is a direct relationship between firm size and the amount of working capital (Dečman and Sever, 2012). Firm size is positively correlated with working capital value. S. Ban os-Caballero et al., (2010) supported the same idea and justified the positive relation because the cost of funds which are used to invest in working capital decreases with firm size. The smaller the firm size the higher the degree of information asymmetry, information opacity, and less followed by analysts. Accordingly, small companies will increase the level of credit sales (Petersen and Rajan, 1997) because they cannot raise capital from other sources of finance. In my study I use firm size as a control variable and my sixth hypothesis is:

H6: There is a positive and significant relationship between SMEs size measured by total assets and working capital measured by CCC.

\subsection{Industry (INDUSTRY)}

Previous studies explained different results regarding the relation between industry and working capital. Different industries manage working capital differently. There are different credit policies and different investment policies in inventories between industries (S. Ban os-Caballero et al., 2010). Accordingly, I will use industry as a control variable to examine its significant effect on working capital.

\section{Research Models, Methodology and Data}

\subsection{Research Models}

The OLS regression models are the most commonly used models in studying the relationships between the dependent and independent variables (Denham, 2010). Accordingly, I used different research models to examine the effect of working capital determinants (as independent variables) on working capital. In our first model (Main model) I used CCC (as a dependent variable) as a measurement of working capital. Also, I examined the effect of working capital determinants (as independent variables) on every component of the cash conversion cycle which includes: the average collection period (AVRG_CP), the average age of Inventory (AVRG_INV) and the average payment period (AVRG_PP) (sub-models). My models are explained as follows:

\section{Model (1):}

$\mathrm{CCC}=\alpha+$ RETURN $\beta 1+$ CASH_FLOW $\beta 2+$ TANG_FA $\beta 3+$ SALES_G $\beta 4+$ LEVERAGE $\beta 5+$ SIZE $\beta 6+$ INDUSTRY $\beta 7+\varepsilon$

\section{Model (2):}

AVRG_CP $=\alpha+$ RETURN $\beta 1+$ CASH_FLOW $\beta 2+$ TANG_FA $\beta 3+$ SALES_G $\beta 4+$ LEVERAGE $\beta 5+$ SIZE $\beta 6+$ INDUSTRY $\beta 7+\varepsilon$

\section{Model (3):}

AVRG_INV $=\alpha+$ RETURN $\beta 1+$ CASH_FLOW $\beta 2+$ TANG_FA $\beta 3+$ SALES_G $\beta 4+$ LEVERAGE $\beta 5+$ SIZE $\beta 6$ + INDUSTRY $\beta 7+\varepsilon$ 
Model (4):

AVRG_PP $=\alpha+$ RETURN $\beta 1+$ CASH_FLOW $\beta 2+$ TANG_FA $\beta 3+$ SALES_G $\beta 4+$ LEVERAGE $\beta 5+$ SIZE $\beta 6+$ INDUSTRY $\beta 7+\varepsilon$

Where:

CCC is a proxy of Working capital measured by cash conversion cycle.

AVRG_CP is a proxy of average collection period

AVRG_INV is a proxy of average age of inventory

AVRG_PP is a proxy of average payment period

$\alpha$ is the intercept of the model

RETURN is a proxy of return on assets

CASH_FLOW is a proxy of cash flow from internal sources

TANG_FA is a proxy of tangible fixed assets

SALES_G is a proxy of sales growth

LEVERAGE is a proxy of leverage

SIZE is a proxy of firm size

INDUSTRY is a proxy of the type of industry

$\varepsilon$ is the error term.

Table 2 summarizes the definition of each dependent, independent and control variables.

Table 2. Definitions of dependent, independent and control variables

\begin{tabular}{|c|c|c|}
\hline Variables & Definition & Measurement \\
\hline \multicolumn{3}{|l|}{ Dependent variable: } \\
\hline Cash Conversion Cycle (CCC) & A proxy measure of working capital. & $\begin{array}{l}\text { (The average collection period }+ \\
\text { average age of inventory - the } \\
\text { average payment period). }\end{array}$ \\
\hline \multicolumn{3}{|l|}{$\underline{\text { Average Collection Period }}$} \\
\hline 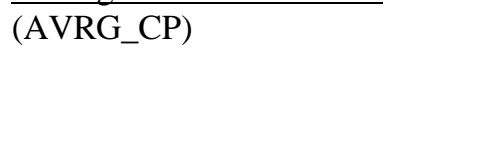 & $\begin{array}{l}\text { The average number of days between } \\
\text { the time a credit sale is initiated until } \\
\text { the credit balance is paid. }\end{array}$ & $\begin{array}{l}\text { (Accounts receivables/ sales) } * 365 \\
\text { days }\end{array}$ \\
\hline $\begin{array}{l}\text { Average Age of Inventory } \\
\text { (AVRG_INV) }\end{array}$ & $\begin{array}{l}\text { The average amount of time it takes } \\
\text { for a company to sell its inventory. }\end{array}$ & $\begin{array}{l}\text { (Inventory/ cost of goods sold) } * 365 \\
\text { days }\end{array}$ \\
\hline $\begin{array}{l}\text { Average Payment Period } \\
\text { (AVRG_PP) }\end{array}$ & $\begin{array}{l}\text { the average number of days between } \\
\text { the time a credit purchases is initiated } \\
\text { until the debit balance is collected }\end{array}$ & $\begin{array}{l}\text { (Accounts payables/ purchases) } \\
* 365 \text { days }\end{array}$ \\
\hline Independent Variables: & Return on assets & (Net income/Total assets) $* 100$ \\
\hline \multicolumn{3}{|l|}{ Return (RETURN) } \\
\hline $\begin{array}{l}\text { Cash flow from internal sources } \\
\text { (CASH_FLOW) }\end{array}$ & $\begin{array}{l}\text { A proxy of the ability of firms to } \\
\text { generate internal sources of finance } \\
\text { in SMEs. }\end{array}$ & $\begin{array}{l}((\text { Net income }+ \text { Depreciation }) / \text { Total } \\
\text { assets }) * 100\end{array}$ \\
\hline Tangible fixed assets (TANG_FA) & $\begin{array}{l}\text { The ratio of tangible fixed assets to } \\
\text { total assets }\end{array}$ & (Tangible assets/ Total assets) $^{*} 100$ \\
\hline Sales growth (SALES_G) & $\begin{array}{l}\text { The ratio of the increase or the } \\
\text { decrease of sales between two years }\end{array}$ & $($ Sales $(\mathrm{t})-$ Sales $(\mathrm{t}-1) /$ Sales $(\mathrm{t}-1)) * 100$ \\
\hline Leverage (LEVERAGE) & The ratio of debt to total assets & $($ Total debt/total assets)*100 \\
\hline \multicolumn{3}{|l|}{ Control Variables: } \\
\hline Firm size (SIZE) & Total assets of the SME. & Total Assets \\
\hline Industry (INDUSTRY) & Type of the industry & $\begin{array}{l}\text { Dummy variable equals } 1 \text { if the SME } \\
\text { is working in a services sector and } \\
\text { zero otherwise. }\end{array}$ \\
\hline
\end{tabular}




\subsection{Sample and Data Collection}

In this study I used the data set of the SMEs which deal with the National bank of Egypt (NBE). I collect judgmental sample of 148 SMEs borrowing from NBE to find out their financial statements for the period of the study from 2010 to 2013. All data have been collected from the financial statements of my sample's companies. All financial ratios have been calculated using income statements and balance sheets of SMEs. Moreover, the types of the industries are stated by NBE in their data set.

\section{Empirical Results}

\subsection{Descriptive Statistics}

Table (3) presents descriptive statistics of dependent, independent and control variables. The mean of CCC is about 124.62 days with minimum -27.20 and maximum 667.50 approximately. That means on average a company can convert cash on hand into inventory and accounts payable, through sales and accounts receivable, and then back into cash in 124.62 days in the Egyptian SMEs. The average of collection period equals 53.45, the average age of inventory equals 97.90 and the average payment period equals 26.16. From one side, the negative values of CCC reflect the long time period of AVRG_PP compared to AVRG_CP and AVRG_INV in some SMEs. The maximum value of AVRG_PP is 229.80 days and that may cause negative values of CCC if the company has low values of AVRG_CP and AVRG_INV. On the other side, the higher values of CCC which equals to 667.50 days in some companies reflects the long time periods of AVRG_CP and AVRG_INV and short time period of AVRG_PP. The long or short time period of CCC reflects conservative or aggressive policy of managing working capital in the Egyptian SMEs.

Table 3. Descriptive statistics

\begin{tabular}{llllll}
\hline Variables & $\mathrm{N}$ & Min & Max & Mean & Std. Dev \\
\hline CCC & 312.00 & -27.20 & 667.50 & 124.62 & 94.96 \\
AVRG_CP & 310.00 & 0.50 & 476.90 & 53.45 & 60.59 \\
AVRG_INV & 311.00 & 1.40 & 700.20 & 97.90 & 81.53 \\
AVRG_PP & 311.00 & 0 & 229.80 & 26.16 & 34.35 \\
RETURN & 411.00 & 0.20 & 87.60 & 19.65 & 14.18 \\
CASH_FLOW & 411.00 & 0.90 & 91.20 & 21.97 & 14.16 \\
TANG_FA & 459.00 & 0 & $124,744.00$ & $7,318.12$ & $14,186.17$ \\
SALES_G & 309.00 & 0.54 & 476.00 & 36.82 & 50.33 \\
LEVERAGE & 421.00 & 0 & 95.80 & 20.40 & 16.00 \\
SIZE & 459.00 & 0 & $555,375.00$ & $18,555.51$ & $44,794.48$ \\
INDUSTRY & 459.00 & 0 & 1.00 & 0.68 & 0.47 \\
\hline
\end{tabular}

Concerning the determinants of working capital of the Egyptian SMEs, table 3 reflects that the mean of RETURN, measured by return on assets, equals $19.65 \%$ with a minimum of $0.20 \%$ and a maximum of 87.60 . The means of the other determinants which are CASH_FLOW, TANG_FA, SALES_G, LEVERAGE and SIZE equal 21.97, 7,318.12, $36.82 \%, 20.40 \%$ and L.E. 18,555, 000 respectively. My data reflects that most of my sample are SMEs working in the services sector and that reflected in table (3) as the mean of INDUSTRY equals 0.68 .

\subsection{Pearson Correlation}

Table (4) presents Pearson correlation coefficients between dependent, independent and control variables. The values of Pearson correlation coefficients indicate that the problem of multicolinearity does non-exist between the independent variables. Only, the Pearson correlation between RETURN and CASH_FLOW equals (.984**). Accordingly, I will consider the probability between these two ratios in my regression to avoid the problem of multicollinearity (Note 3). 
Table 4. Pearson correlation coefficients between dependent, independent and control variables.

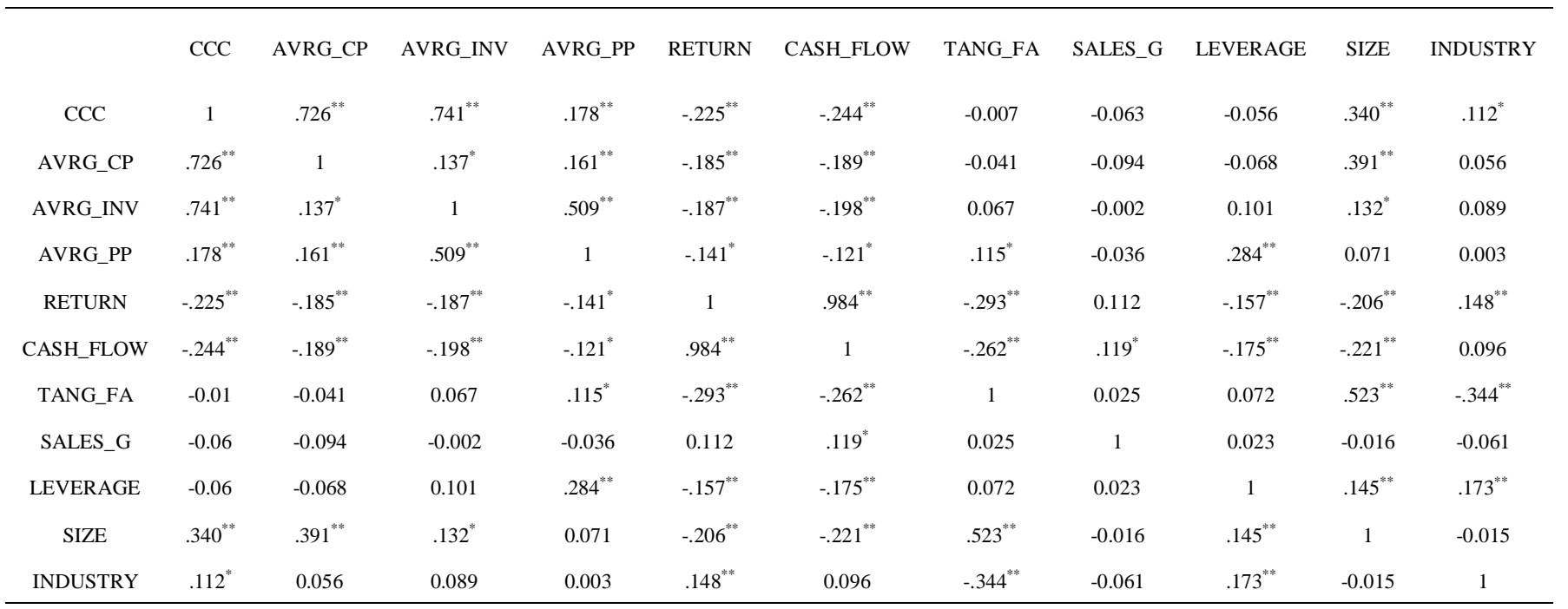

**. Correlation is significant at the 0.01 level (2-tailed).

*. Correlation is significant at the 0.05 level (2-tailed).

\subsection{OLS regression Results:}

\subsubsection{Working Capital Determinants and CCC:}

The study regression models show a multicollinearity problem between RETURN and CASH_FLOW. Accordingly, I examined the effect of working capital determinants using RETURN or CASH_FLOW and avoid inserting them in the same regression model to solve the multicollinearity problem. Table (5) shows the results of the OLS models using RETURN in the first regression and CASH_FLOW in the second regression.

Table 5. OLS models using RETURN and CASH_FLOW (full models)

\begin{tabular}{llllll}
\hline Model 1 & \multicolumn{7}{c}{ Model 2 } \\
\hline & $\mathrm{B}$ & Sig & & $\mathrm{B}$ & Sig \\
\hline (Constant) & 131.407 & .000 & (Constant) & 132.551 & .000 \\
RETURN & -1.091 & .002 & CASH_FLOW & -1.011 & .005 \\
TANG_FA & -.002 & .013 & TANG_FA & -.001 & .021 \\
SALES_G & $2.279 \mathrm{E}-5$ & 1.000 & SALES_G & -.008 & .943 \\
LEVERAGE & -1.124 & .001 & LEVERAGE & -1.116 & .001 \\
SIZE & .002 & .000 & SIZE & .002 & .000 \\
INDUSTRY & 29.262 & .025 & INDUSTRY & 28.188 & .032 \\
F & 14.197 & .000 & F & 13.906 & .000 \\
R Square & .286 & & R Square & .281 &
\end{tabular}

Table (5) explained the OLS model which examines the effect of working capital determinants on CCC as a measure of working capital. The R Square of the first model equals 0.286 which means that my independent variables explained $28.6 \%$ of changes in working capital measured by CCC. The model is significant at $1 \%(\mathrm{~F}=14.197)$. The results of the model indicate a negative and significant effect of RETURN, TANG_FA and LEVERAGE. That means, the higher the rate of return, the value of tangible fixed assets, and leverage, the lower the degree of working capital measure by CCC. Also, the results reflect a positive and significant effect between company size and industry, and CCC. That means the larger the size of SMEs the higher the value of working capital measured by CCC. Also, the industry represents a significant factor in determining the level of working capital in the Egyptian SMEs.

Model (2) in table (5) uses CASH_FLOW on behalf of RETURN as a determinant of working capital. The R Square of model (2) equals 0.281 which means that my independent variables explained $28.1 \%$ of changes in working capital measured by CCC. The model is significant at $1 \%(\mathrm{~F}=13.906)$. The model reflects the same results of the 
Model (1) table (5). Accordingly, in the following models I will use RETURN as a determinants as the goodness of fit of Model (1) (R square $=28.6 \%)$ are better than Model (2) $(\mathrm{R}$ square $=28.1)$. According to my first and second models in table (5), all my hypotheses have been accepted except hypothesis (4). The results reflect a positive but insignificant relation between sales growth and CCC in both models.

\subsubsection{Working Capital Determinants and the Components of CCC}

Table (6) presents the OLS regression results of the relation between working capital determinants and each component of CCC. The components of CCC include the average collection period (AVRG_CP), the average age of inventory (AVRG_INV) and the average payment period (AVRG_PP). Each regression model explains the relation between working capital determinants and each component of CCC.

The R Square of the first model equals 0.283 which means that my independent variables explained $28.3 \%$ of changes in include average collection period (AVRG_CP). The model is significant at 1\% ( $\mathrm{F}=13.983)$. The regression model reflects a negative and significant relation between RETURN, TANG_FA and LEVERAGE and AVRG_CP. That means, SMEs with higher performance rate, higher degrees of tangible fixed assets and leverage will have lower average collection period and means good policy in collecting their credit sales. On the other side, the results of the same model reflect a positive and significant relation between SIZE and AVRG_CP. That means larger the size of the Egyptian SMEs the higher the number of days in collecting their credit sales.

The R Square of the second model equals 0.112 which means that my independent variables explained $11.2 \%$ of changes in the average age of inventory (AVRG_INV). The model is significant at 1\% ( $\mathrm{F}=4.492)$. The regression model reflects a negative and significant relation between RETURN and AVRG_INV. That means, higher degrees of SMEs profitability is related with shorter time periods of holding inventories. Also, the second model, table 6, reflects a positive and significant relation between SIZE and INDUSTRY with AVRG_INV. That means larger the size of SMEs, specifically in services industry, the longer the time period of holding inventories.

The R Square of the third model, table 6, equals 0.0.071 which means that my independent variables explained 7.1\% of changes in the average age of inventory (AVRG_INV). The model is significant at 5\% ( $\mathrm{F}=2.296)$. The regression model reflects a positive and significant relation between LEVERAGE and AVRG_PP. That means longer time periods of paying SMEs credit sales is affected by higher levels of debt.

Table 6. Working capital determinants and the components of CCC

\begin{tabular}{lllllllll}
\hline AVRG_CP & \multicolumn{7}{c}{ AVRG_INV } & \multicolumn{7}{c}{ AVRG_PP } \\
\hline & B & Sig & & B & Sig & & B & Sig \\
\hline (Constant) & 77.841 & .000 & (Constant) & 65.682 & .000 & (Constant) & 12.117 & .106 \\
RETURN & -.672 & .008 & RETURN & -.548 & .086 & RETURN & -.129 & .442 \\
TANG_FA & -.002 & .000 & TANG_FA & .001 & .111 & TANG_FA & .000 & .102 \\
SALES_G & -.066 & .412 & SALES_G & .044 & .670 & SALES_G & -.022 & .679 \\
LEVERAGE & -.831 & .001 & LEVERAGE & .159 & .604 & LEVERAGE & .452 & .006 \\
SIZE & .001 & .000 & SIZE & .000 & .059 & SIZE & -3.752 E-5 & .742 \\
INDUSTRY & 1.432 & .875 & INDUSTRY & 31.414 & .007 & INDUSTRY & 3.584 & .558 \\
F & 13.982 & 0.000 & F & 4.492 & 0.000 & F & 2.696 & 0.015 \\
R Square & .283 & & R Square & .112 & & R Square & .071 & \\
\hline
\end{tabular}

5.3.3 The Effect of Working Capital Management of SMEs Profitability and Capital Structure Decisions

Table (7) presents the effect of working capital management and SMEs profitability and capital structure decisions. The first regression model reflects a negative and significant relation between CCC and RETURN (measured by ROA). That means, the longer the CCC the lower the rate of return in the Egyptian SMEs and Vice versa. Also, it reflects and positive and significant relation between SIZE and INDUSTRY and RETURN which means the size and industry of SMEs have significant and positive effects on firms' profitability. The larger the size of SME, especially in service sector, the higher the rate of return.

In the second regression model, table 7, I examine the relation between CCC and SMEs leverage. The results reflect a negative and significant effect of CCC and SMEs leverage. That means the shorter the CCC time period the higher the level of debt in the Egyptian SMEs. My results are consistent with (Chiou et al., 2006; Rahman and Nasr, 2007; S. 
Baños-Caballero et al., 2010, Abbadi and Abbadi, 2013). Also, regression results reflect and positive and significant relation between SIZE and INDUSTRY and LEVERAGE which means the size and industry of SMEs have significant and positive effects on firms' leverage. The larger the size of SME (measured by its total assets) the higher the rate leverage ratio.

Table 7. The effect of working capital management of SMEs profitability and capital structure decisions

\begin{tabular}{llllll}
\hline RETURN & \multicolumn{5}{c}{ LEVERAGE } \\
\hline & $\mathrm{B}$ & $\mathrm{Sig}$ & & $\mathrm{B}$ & $\mathrm{Sig}$ \\
\hline (Constant) & 22.047 & 0 & (Constant) & 16.827 & .000 \\
CCC & -0.026 & 0.003 & CCC & -.026 & .005 \\
SIZE & 0.000 & 0.001 & SIZE & .000 & .000 \\
INDUSTRY & 4.407 & 0.013 & INDUSTRY & 7.735 & .000 \\
F & 12.594 & 0 & F & 10.370 & .000 \\
R Square & 0.11 & & R Square & .092 & \\
\hline
\end{tabular}

The first and second regression models of table (7) reflect that the Egyptian SMEs follow an aggressive policy as businesses hold low level working capital which leads to high return and high degree of risk.

\subsection{Robustness Analysis}

Table (8) presents the robustness analysis of my study. It reflects the effect of working capital determinants on CCC between years. I repeated the full regression model for each year from 2010 to 2013. In the first regression model I exclude SALES_G from my regression model as I do not have data of 2009 to calculate sales growth ratio.

Table 8. the effect of working capital determinants on CCC between years

\begin{tabular}{|c|c|c|c|c|c|c|c|c|c|c|c|}
\hline \multicolumn{3}{|c|}{2010} & \multicolumn{3}{|c|}{2011} & \multicolumn{3}{|c|}{2012} & \multicolumn{3}{|c|}{2013} \\
\hline & B & $\mathrm{Sig}$ & & B & Sig & & B & Sig & & B & Sig \\
\hline (Constant) & 169.990 & .000 & (Constant) & 100.089 & .001 & (Constant) & 152.491 & .000 & (Constant) & 120.221 & .002 \\
\hline RETURN & -1.646 & .163 & RETURN & -.947 & .176 & RETURN & -.889 & .104 & RETURN & -1.181 & .098 \\
\hline TANG_FA & -.005 & .022 & TANG_FA & -.001 & .183 & TANG_FA & -.002 & .025 & TANG_FA & .002 & .447 \\
\hline SALES_G & - & - & SALES_G & .025 & .867 & SALES_G & -.083 & .728 & SALES_G & .089 & .846 \\
\hline LEVERAGE & -.759 & .460 & LEVERAGE & -1.707 & .015 & LEVERAGE & -1.201 & .029 & LEVERAGE & -.545 & .427 \\
\hline SIZE & .003 & .002 & SIZE & .002 & .000 & SIZE & .002 & .000 & SIZE & .001 & .520 \\
\hline INDUSTRY & 1.357 & .972 & INDUSTRY & 59.746 & .013 & INDUSTRY & 6.391 & .749 & INDUSTRY & 39.499 & .164 \\
\hline $\mathrm{F}$ & 3.256 & .012 & $\mathrm{~F}$ & 7.905 & .000 & $\mathrm{~F}$ & 6.225 & .000 & $\mathrm{~F}$ & 1.428 & .221 \\
\hline R Square & .2 & & R Square & .4 & & R Square & .3 & & R Square & .1 & \\
\hline
\end{tabular}

The robustness analysis shows differences between the years of analysis. RETURN is only negatively and significantly related to CCC in year 2013. TANG_FA is only negatively and significantly related to CCC in year 2010. SALES_G is insignificant in all models and all years. LEVERAGE is negatively significant with CCC in years 2011 and 2012. SIZE is positively significant with CCC in all years except 2013. Finally, INDUSTRY are only positively and significantly related to CCC in year 2011. The robustness analysis reflects the year effect of managing working capital in the Egyptian SMEs. I interpret these results as Macro and micro economic, political and social effects may change the working capital policy of SMEs.

\section{Conclusion}

In this study I explore the main determinants of working capital management in the Egyptian SMEs. I use the most common determinants of working capital which have been examined in previous literature. SMEs return on assets, Cash flow from internal sources, tangible fixed assets, sales growth, leverage, size and industry were the most common used determinants of working capital management in literature.

My sample includes 148 SMEs from 2010 to 2013 and all data have been collected from the financial statements of the SMEs. I used OLS regression models to extract my results. The main results reflect a negative and significant 
effect of RETURN, TANG_FA and LEVERAGE. That means, the higher the rate of return, the value of tangible fixed assets, and leverage, the lower the degree of working capital measure by CCC. Also, the results reflect a positive and significant effect between company size and industry, and CCC. That means the larger the size of SMEs the higher the value of working capital measured by CCC. Also, the industry represents a significant factor in determining the level of working capital in the Egyptian SMEs.

The effect of working capital determinants on each component of $\mathrm{CCC}$ has been examined and I find a negative and significant relation between RETURN, TANG_FA and LEVERAGE and AVRG_CP. Also, I find a positive and significant relation between SIZE and INDUSTRY and AVRG_CP. Moreover, I find a negative and significant relation between RETURN and AVRG_INV. Also, I find a positive and significant relation between SIZE and INDUSTRY with AVRG_INV. Finally, I find a positive and significant relation between LEVERAGE and AVRG_PP.

The effect of working capital management and SMEs profitability and capital structure decisions has been examined and I find that the Egyptian SMEs follow an aggressive policy as businesses hold low level working capital which leads to high return and high degree of risk (measured by LEVERAGE).

This study is limited to 148 Egyptian SMEs dealing with the national bank of Egypt from 2010 to 2013. The study can be extended to other countries or different time series. SMEs' investors and financial institutions can use my results as a guidance of determining the suitable level of working capital and in determining the most effective factors of working capital management of the Egyptian SMEs.

\section{References}

Abbadi, S. M., \& Abbadi, R. T. (2013). The Determinants of Working Capital Requirements in Palestinian Industrial Corporations. International JMynal of Economics and Finance, 5(1), 65-75.

Chiou, J. R., L. Cheng, \& H. W. Wu. (2006). The determinants of working capital management. Journal of American Academy of Business, 10, 149-155.

Cohen J, P. Cohen, S. G. West, L. S. Aiken. (2003). Applied Multiple Regression/Correlation Analysis for the Behavioral Science. Mahwah, Nj. - Lawrence Erlbaum.

Creative Associates International. (2014). Micro, small and medium size enterprises in Egypt: Entrepreneurship, Business Procedures and Chain Analysis. https:/41pylqn86jp37e3n04us8vqq-wpengine.netdna-ssl.com/wp-content/uploads/2003/01/Micro_Small_and-_ Medium_Enterprises_in_Egypt.pdf

Dečman, Nikolina \& Ivana Sever. (2012). Liquidity management in small and medium sized entities. International Conference of the Faculty of Economics, Sarajevo, 685-693.

Deloof, M. (2003). Does working capital management affect profitability of Belgian firms? Journal of Business, Finance and Accounting, 30, 573-587. https://doi.org/10.1111/1468-5957.00008

Fazzari, S. M., \& B. Petersen. (1993). Working capital and fixed investment: new evidence on financing constraints. Rand Journal of Economics, 24, 328-342. https://doi.org/10.2307/2555961

Garcia-Teruel, P. J., \& P. Martinez-Solano. (2007). Effects of working capital management on SME profitability. International Journal of Managerial Finance, 3, 164-177. https://doi.org/10.1108/17439130710738718

Gibson Tom \& H. J. van der Vaart. (2008). Defining SMEs: A Less Imperfect Way of Defining Small and Medium Enterprises in Developing Countries. Brookings Global Economy and Development, September, 1-29.

Gitman, L. J., \& Zutter, C. J. (2015). Principles of managerial finance, 13th ed., Boston: Pearson Prentice Hall.

Goel, Utkarsh; Sharma, Anil K. (2015). Working Capital Management Efficiency in Indian Manufacturing Sector: Trends and Determinants. International Journal of Economics and Business Research, 10(1), 30-45. https://doi.org/10.1504/IJEBR.2015.070273

Jose, M. L., C. Lancaster, \& J. L. Stevens. (1996). Corporate return and cash conversion cycle. Journal of Economics and Finance, 20, 33-46. https://doi.org/10.1007/BF02920497

Kieschnich, R., M. LaPlante, \& R. Moussawi. (2006). Corporate working capital management: determinants and consequences. working paper, University of Texas, Dallas.

Kieschnich, R., M. LaPlante, \& R. Moussawi. (2006). Corporate working capital management: determinants and consequences, working paper (University of Texas, Dallas). 
Lazaridis, L \& Tryforidis, D. (2006). The Relationship between Working Capital Management and Profitability of List Companies in the Athens Stock Exchange. Journal of Financial Management and Analysis 1(19), 26-350.

Malik, Mohammad Shaukat \& Mahum Bukhari. (2014). The Impact of Working Capital Management on Corporate Performance: A Study of Firms in Cement, Chemical and Engineering Sectors of Pakistan. Pak J Commer Soc Sci, 8(1), 134- 148.

Moukhtar, Y. \& Ahmed Abdelwahab. (2015). SMEs in Egypt: Current state and challenges. The Egyptian centre for public policy Studies, 1-16.

Nazir, M. S., \& Afza, T. (2009). Working Capital Requirements and the Determining Factors in Pakistan. The Icfai Journal of Applied finance, 15(4), 28-37.

Petersen, M. A., \& Rajan, R. G. (1997). Trade credit: Theories and Evidence. Review of Financial Studies, 10(3), 661-691. https://doi.org/10.1093/rfs/10.3.661

Raheman, A., \& M. Nasr. (2007). Working capital management and profitability - case of Pakistani firms. International Review of Business Research Papers, 3, 275-296.

Rostami, Anvari; A. A.; SadjadpMy, R. \& yaballuei, M. (2014). An Investigation of the Determinants of Working Capital Management in Tehran Stock Exchange (TSE). Journal of Financial Accounting Research, 6(1), 1-13.

S. Baños-Caballero, Pedro J. Garci'a-Teruel \& Pedro Martı'nez-Solano. (2010). Working capital management in SMEs. Accounting and Finance, 50, 511-527. https://doi.org/10.1111/j.1467-629X.2009.00331.x

S. Baños-Caballero, Pedro J. Garci'a-Teruel \& Pedro Martı'nez-Solano. (2012). How does working capital management affect the profitability of Spanish SMEs? Small Bus Econ, 39, 517-529. https://doi.org/10.1007/s11187-011-9317-8

Samiloglu, F., \& Dermigunes, K. (2008). The effect of Working Capital Management on Firm Profitability: Evidence from Turkey. The International JMynal of Applied Economics and Finance, 2(1), 44-50. https://doi.org/10.3923/ijaef.2008.44.50

Shin, H. H., \& L. Soenen. (1998). Efficiency of working capital and corporate profitability. Financial Practice and Education, 8, 37-45.

Smith, K. (1980). Profitability versus liquidity tradeoffs in working capital management. In K. V. Smith (Ed.), Readings on the management of working capital (pp.549-562). St Paul, MN: West Publishing Company.

Supatanakornkij, Sasithorn. (2014). The Determinants of Working Capital Management: Evidence from European Companies. Annual International Conference on Accounting \& Finance, 151-154. https://doi.org/10.5176/2251-1997_AF14.35

\section{Notes}

Note 1. http://www.mof.gov.eg/MOFGallerySource/Arabic/Small_Projects/law141-2004.pdf

Note 2. https://oxfordbusinessgroup.com/news/sme-financing-ramps-egypt

Note 3. The rule of thumb is that any VIF of 10 or more provides evidence of serious multicollinearity (Cohen et al., 2003). 